\title{
English Use and Western Cultural Interference in Minangkabau Wedding Ceremony in Padang City
}

\author{
Rina Marnita \\ \{rinamarnita@hum.unand.ac.id\} \\ English Department, Andalas University, Padang, Indonesia
}

\begin{abstract}
Almost every ethnic group in the world has a culture that distinguishes it from other ethnic groups. This study investigates the influence of Western culture in today' Minangkabau wedding ceremony by observing the use of English words, phrases and cultural terms used in various elements of Minangkabau wedding ceremony in Padang City. The study is to find the implication of the use the expressions to the Minangkabau values and culture from the anthropological, linguistic perspective. The data was collected by visiting or attending some wedding parties held in some hotels and buildings in the city, observing 50 wedding invitations, observing the uploaded photos of wedding ceremonies on Instagram or Facebook, collecting various ornaments and properties used in the ceremony. Some interviews were conducted to obtain first-hand information and opinion from parents, brides and brooms, quests, and people working in the printing houses. The study reveals that thee adoption of the English expressions, intentionally or unintentionally, consciously or unconsciously, has to some degree showed some influences of the Western and Christian belief or practices in the Minangkabau wedding tradition, at least those held in the Padang city. In negative result of language contact, the adoption of the English language in the element of Minangkabau wedding may mean the negligence of Minangkabau people to its tradition and religion.
\end{abstract}

Keywords: Minangkabau wedding ceremony, English language, cultural interference, and linguistic anthropology.

\section{Introduction}

Minangkabau is an ethnic group primarily lives in the area on the west coast of Sumatra, Indonesia. It is widely recognised as one of the most Islamised regions in Indonesia and has a traditional unwritten code that is called 'adaik or adat' that governs almost all aspects of the personal conduct of the indigenous people.

The adaik is distinguished into four types, namely: 1. Adaik nan sabana Adaik; 2. Adaik nan diadaikkan ; 3. Adaik nan Taradaik; and 4. Adaik Istiadaik. The adaik nan sabana adaik is the main but unchangeable adat. It is a fixed price that one cannot be said to be a Minang person if he does not carry out this custom. Adaik nan diadaikkan is a rule that has been agreed upon and promulgated in the Minangkabau Customary Order from ancient times. The most basic one is the practice of the matrilineal kinship. Adaik nan Taradaik or Adaik salingka nagari regulates the order of community life in a Nagari and the interaction between one tribe and another tribe in the nagari that is adapted to the culture in the area itself but must still refer to the teachings of Islam. This custom is a mutual agreement between the Ninik mamak Penguhulu, Alim ulama, Cadiak pandai, Bundo Kanduang and Pemuda in a nagari, which is adapted to the times and the 
basic ethics of Minang custom. Adaik Istiadaik relates to the implementation of human relationship, communication, integration, and socialision in the community of a Nagari. This adat may vary from one region to another but still refers to the teachings of Islam. Wedding ceremony is one practice of adiak istiadaik.

Despite variation in practice between one nagari with another, the Minangkabau wedding ceremony today has some practices adopted from oher cultures. Javanese tradition such as sungkeman, munduh mantu, seserahan and pagar ayu, for examples, are now commonly found in the wedding practices of the Minangkabau. Western wedding tradition such as as the design of the wedding dress and the ornaments used, is also observed. This is particularly reflected in the English terms and expressions used in the wedding ceremony.

The adoption of the foreign linguistic element by a particular community may be the result of contact, intentionally or unintentionally. As mentioned in literature [3]-[9], the contacts between people of two different cultures often result in language contact as well. The result my be considered positive as it contributes to the development of the local language, advance in science and technology, widen the people's knowledge and insight, or negative as it may endanger the existence of the native language. This aims to investigate the meaning of the use of English language in Minangkabau wedding ceremony and its implication to the Minangkabau culture, that is adat, tradition, and Islam. As a preliminary study, the study is limited to the practice of wedding ceremonies conducted by people in Padang city during the last two years.

\section{Methods}

This research is a field study that observes the practice of wedding ceremonies, including Akad Nikah and the wedding party, in Padang city. The source of data are all objects used in the wedding ceremonies such as invitation card, ornaments such as clothing, flowers, jewelry, and all practices related to the wedding. Data were collected through direct observation by recording the weddings, the ornaments used, and observation of the objects used in the weddings. This method is supported by interviewing various peoples covering the owners and staff of some printing houses, some photographers, the brides and her families, master of ceremonies, providers of catering, and wedding organiser. Data is also taken from the social media of the brides being observed such as the brides or brooms' photos on Instagram or Facebook, and advertisements by the photographers, bridals and catering providers. Data is collected using a snowball sampling method.

Data analysis of this results of this research is done by referring to what was conveyed by [3], [13], [14] and [15] about how contact between speakers of language can bring cultural contact, and that cultural contact occurs in what is called social space and is increasingly possible in today's global world. Moreover, the adoption of other cultures by a community group includes the desire to realize themselves as a group with a more acceptable identity. In addition, the analysis also refers to the fact that English is the world language whose use has entered almost all aspects of human life. 


\section{Minangkabau Wedding Tradition}

In general, it is stated that the Minangkabau community is a Muslim community. The Minangkabau community made Islam a foundation of life, including in carrying out marriage. The wedding program that is carried out is not by the teachings of Islam is considered a nonMuslim marriage.

In Islam, a wedding is a marriage promise binding ceremony carried out by prospective bride and broom with the aim of legalizing the relationship between two sexes who will live on one roof both legal norms of religion, legal norms and social norms. The wedding reception is called walimah and is orgnised following rules: 1) using a separator between men and women to avoid the mixing between men and women who are not mahram in a room; 2) no sight that falls on adultery between guests who are not mahram; and 3) no handshake between the bride and the non-mahram. However, even though they are the most Islamized society [2], they primarily practice the Minangkabau wedding tradition, called baralek.

The word baralek is used both to the wedding ceremony as a whole and the wedding reception itself. In general, baralek begins with maninjau (exploration), maminang (asking for a marriage), batimbang tando (asking for marriage and exchanging rings or other objects) and manantukan hari (determining the day). After akad nikah or the marriage ceremony, the bride's family helds malam bainai (nail painting). The wedding reception begins with the activity called manjapuik marapulai, that is 'picking-up' the broom from his house. This is done by a group of people from the bride's family usually consists of sumandan (wives of male relatives) who carry a complete set of clothes, sticky or glutionous yellow rice, roasted chicken, bananas, cakes, and some other traditional food, mamak and niniak mamak/pengulu. This picking up is usually accompanied by sounds like talempong and tambur or music. Mamak or ninik mamak expertise in delivering traditional speeches will determine the length of time for negotiations between the men and women in releasing the bridebroom to take home to the women's house. Usually after eating, the broom can be brought to the women's home, where bridebroom are juxtaposed in the aisle to receive a greeting until the evening.

\section{Language and Cultural Contact}

Since the beginning of human civilisation, contact between people of different culture and language is undeniable. The contacts between people of two different cultures often result in language contact as well [1,2 ]. As stated by [10], contact between two different communities will lead to language contact and change in language. Language contact mainly takes place where and if only two or more groups /groups of people of different languages (and generally also different cultures and views) meet and wish to communicate, whether intentionally or unintentionally, egalitarian or not, mutually beneficial or not, peaceful or not.

Concerning language, as members of social groups, and as individual actors, speakers of a language indeed use language creatively to express and negotiate complex and shifting identities. Bucholtz and Hall [1] state that this is aimed to convince and advance their interest and achieve specific goals. Moreover, language contact, anywhere, can have different outcomes, ranging from stable bilingualism or multilingualism to the death of one or more of the languages involved [1]: pidgin and creole; code switching and code mixing [5] " crossing " [3], shifting language $[4,7]$, and ignorance of language and language death $[6,2]$. 
Anthropology considers inter-language contact to occur not due to the contact of the language itself but by contact between speakers of a language, which occurs in historical and social contexts. It happens from specific contacts such as souvenir transactions between tourists and residents to long or long contact between two large populations that are very different in culture and language, such as contacts generated by European colonisation, and various forms produced by globalisation [11], [12]. According to [13], all these episodes of contact appear in what he calls 'contact zones', which is a kind of 'social space' where groups of humans who were previously geographically and historically separated, establish contact with each other.

Contact between people from around the world today is enabled by the advance in the technology of communication and transportation. Undeniably, English as the most widely spoken language in the world has developed into the language of the world and functions as Lingua franca.

The use of English language in the wedding ceremony of the Minangkabau will be studied from the perspective of linguistic anthropology [3]. According to [3], the basic assumption in linguistic anthropology is that to understand the meaning of a language message (linguistic message) is to study the context in which the message is produced (produced) and interpreted (interpreted). A set of analytical tools must support meaning based on this context outside of words, sentences and languages as an ideal communication system, which includes speech communities, speech events, activities and acts as well as variety. language use (register) and language variations (variety / language variations).

\section{The Use of English in Minangkabau Wedding Ceremony and Its Cultural Implication}

This research shows that there are English words used in the wedding ceremony of the Minangkabau in Padang. The words or terms borrowed are used to refer to the categories of: 1) Objects; 2) Concepts; and 3) Activities. Each is described below:

\subsection{Objects}

1) Invitation Cards

It is found that the English language is used in both printed and online invitation cards. In the printed version, it is found particularly on the cover or envelope of the card. The word UNDANGAN (invitation) is replaced by the English word or phrases 'The Wedding' or "The wedding of', followed by the name of the bride and the broom. In the online version published either in social media or Youtube, , either in the form of videos or slides show, the information about the marriage is longger, like 'We are getting married. Ica \& Faris, together withour families invite you to celebrate our wedding”. In the video, the information is even longer: We're getting married. You are invited. Join us on my wedding tomorrow..part 2. Save the date.The Wedding of Rendi and Selvy. Reception on ....

Other private information about the bride relationship is also stated and written in English accompanied by animations that describe events, such as: - First met ........ February 2012 Relationship .... September 2012-2017, - Traveling ....- Engagement ..... April 232017

2) Bridesmaids

Having some pengiring pengantin or bridesmaids in English is becoming a trend today among young people's wedding. Usually, the companions are close friends of the bride or broom. To invite these attendees formally, even though they are also already informed orally, 
special cards are often made. Of the several cards found, the sentences used are generally in English language, as found in a card below:

Dear, will you be my bridesmaids?

Save the date

Sunday: July 162017

Rohana Kudus, Padang

It would be an honor to have your presence and blessing on our wedding

\section{3) Ornament of Photobooth}

Today the bride family often provides a place which is design in such a way for the guest to take pictures. This photo spot, called Photobooth, usually has lots of ornaments such as backgrounds or backdrop, chairs/bench, small table, flowers, the bride and the brooms prewedding photoes, lights, and cards that are hol by the quests when they take photo at the photobooth. The English expressions found in the photobooth include: The wedding of...; Just got married; Not anymore single; Mr Right and Mrs. Always Right. This photobooth, together with the ornaments do not belong to Minangkabau wedding tradition nor the culture of the people. However, it is a kind of a must to some Minangkabau young people. It is also hard to say that it belongs to the western culture as it is not practised by people in England, USA or Europe in general. It could be a creation of the people as many people today like to document the event they like. To some families, it function to show their identity as Minangkabau modern families.

\subsection{Concepts}

It is found that some English words used in the wedding ceremonies bear Western concepts of wedding traditon or religion. They are among others are:

a. The word 'the wedding'. It is often commonly used in the cover invitations and the expression of congratulations on bouquets. This word refers to a ritual event in western culture and Christian tradition.

b. Altar, is a term used by some wedding providers to refer to a place with two brides, both in the building and at home. In English, the word altar eans a place where pastors carry out religious speech, blessings of marriage, and baptism in Christianity.

c. Bridesmaid, is a term refers to the companions of the bride who is still single.

\subsection{Activity}

It is often also found the brides who hold bridal flowers at the marriage ceremony and wedding reception. Sometimes, the flowers are thrown into a crowd of guests to be captured by their friends. Using flowers in weddings has been done since ancient Rome, both by Greeks and Romans. Roses, lilies or orchids are pinned on the bride's hair as they believe that the smell from the flower of the bride can smell evil spirits. In its history, after the wedding was over, the bridesbroom eat the flowers as it was believed to increase sexual desire.

Referring to [3], [13], [14] and [15], about how contact between speakers of a language can bring cultural contact, and that cultural contact occurs in what is called social space and is increasingly possible in today's global world, some findings can be described. The word 'wedding, altar, bridesmaids and the use of bridal flower reflect the existence of foreign cultures in the society. As stated by a photographer, English is very commonly used in the photographer world, and wedding ornaments as young people in the city prefer to use English expression than Indonesian for their invitation cards and other wedding ornaments. According to some staff of 
the printing houses, the choice of the word to use on the invitation cards is decided by the bride or the broom, not the parents

The use of the English language on the invitation card, in particular, reflects Minangkabau young people's acceptance of a foreign culture. Referring to the literature [3], [4], and [5], this shows that as members of social groups and individual actors, the young people use language to express and negotiate their identities (complex and shifted), to convince and advance their interest, and achieve specific goals. They want to be part of modern society as it is pictured on various social media. It is reflected from the statements of some brides who believed that to be updated is very important in order not to be considered to be left behind. The use of the Bridal flowers, for example, indicates adoption of part of Western wedding tradition as it does not exist in Minangkabau wedding tradition.

The adoption of foreign culture has marked the history of the development of Minangkabau culture. It is possible, as described by [18], Minangkabau people may easily adapt to a new culture, and thus is widely known as being adaptive and tolerance. The fact that the use of English in various parts of the wedding ceremony by young people today may mean adoption of Christian values may not be of the people awareness.

\section{Conclusion}

Using Aunt Chloe's kitchen, Stowe shows how slavery erases all hope of a constant domestic life where families can have stability and control in their lives. Uncle Tom, the claimed hero of Uncle Tom's Cabin, sits at a kitchen table when he is introduced to the story. The reader's first glimpse of Uncle Tom is in a kitchen, which seems to suggest that he is safe in his home with his family, that the cruelty of slavery cannot break his spirit. However, this false sense of security is shattered, the reader knows that while Tom is enjoying dinner with his wife and children in his loving, domestic kitchen, Mr. Shelby is planning his separation from them. It is this contradiction that Stowe creates to show the incompatibility of domestic life and slavery and to give the Northern reader a reason to fight slavery. " The sacred ties envisioned in Stowe's cabin scene are swept away by Master Shelby's debt and its resolution in the sale of slaves who have been nurtured as a family." Stowe purposely contrasts Chloe and Dinah's kitchens. One is an outright demonstration of slavery's negative effect on the Southern home, while the other is disguised with false images of domesticity. However, Stowe wants the reader to realize that both homes display an ingrained belief and acceptance of slavery, separate spheres, social structure, lack of control, and limited sentimentality, all of which deny domestic freedom within their walls.

In the final pages of Uncle Tom's Cabin, Stowe directly addresses the reader: But what can any individual do? Of that, every individual can judge. There is one thing that every individual can do; they can see to it that they feel right. An atmosphere of sympathetic influence encircles every human being, and the man or woman who feels strongly, healthily and justly, on the significant interests of humanity, is a constant benefactor to the human race. See, then, to your sympathies in this matter! (624) Uncle Tom's Cabin spoke to each Northerner who read its pages, forcing her to view slavery from a new perspective, sympathize with the slave characters, and relate the novel to things she knew all too well, family, sentimentality, and the Cult of Domesticity. Above all, Harriet Beecher Stowe wanted her white audience to take action against slavery. 


\section{References}

[1] Abdullah, T 1966. dalam Adat and Islam: an examination of conflict in Minangkabau. Indonesia, Volume 2 (1-24).

[2] بولي إلا نكاح لا Hadits riwayat Ahmad (hadits nomor 8697), Abu Daud (hadits nomor 2085), Tirmidzi (hadits nomor 1101), Hakim (II/185)

[3] Duranti, A. (2003). Language as Culture in U.S. Anthropology: Three Paradigms. Current Anthropology 44(3): 323-347.

[4] Appel, R., and Pieter Muysken. 1987. Language contact and bilingualism. London: Edward Arnold.

[5] Thomason, Sarah, and Terrence Kaufmann. 1988. Language contact, creolization and genetic linguistics. Berkeley: University of California Press.

[6] Gumperz, J. Language Contact (1979). Cambridge Press

[7] Woolard, K. A. (1989a). Double Talk: Bilingualism and the Politics of Ethnicity in Catalonia. Stanford: Stanford University Press.

[8] Gal, S. (1979). Language Shift: Social Determinants of Linguistic Change in Bilingual Austria. New York: Academic Press.

[9] Crystal, D. (2000). Language Death. Cambridge: Cambridge University Press.

[10] Dorian, N. C. (ed.) (1989). Investigating Obsolescence: Studies in Language Contraction and Death. Cambridge: Cambridge University Pres

[11] Appadurai, A. (1996). Modernity at Large: Cultural Dimensions of Globalization. Minneapolis: University of Minnesota Press.

[12] Duranti, A. (2001b). Intentionality. In A. Duranti (ed.), Key Terms in Language and Culture (pp. 129-131). Malden, MA: Blackwell.

[13] Hannerz, U. (1996). Transnational Connections: Culture, People, Places. London: Routledge.

[14] Kulick, D. (1992). Language Shift and Cultural Reproduction: Socialization, Self, and Syncretism in a Papua New Guinean Village. Cambridge: Cambridge. Univ.

[15] Pratt, M.L. (1992). Imperial Eyes:TravelWriting and Transculturation. London: Routledge

[16] Miller-Wilson, Kate (2015). History of Western Wewdding. Love to Know.com

[17] Monger, G. 2004. Marriage Customs of the World: From Henna to Honeymoons.ABC-CLIO p. 159. ISBN 978-1-57607-987-4. Retrieved I January 2013

[18] An-Na'im,A. 2002. Islamic Family Law inA Changing World: A Global Resource Book. Zed Books. p. 254. ISBN 978-1- 84277-093-1. Rerieved 1 January2013. 